\title{
RELASI EKSEKUTIF - LEGISLATIF DALAM PRESIDENSIALISME MULTIPARTAI DI INDONESIA
}

\author{
Firman Manan \\ Departemen Ilmu Politik Universitas Padjadjaran, Bandung, Indonesia \\ E-mail: firman.manan@unpad.ac.id
}

\begin{abstract}
ABSTRAK
Pengadopsian presidensialisme multipartai di Indonesia sejak tahun 2004 menimbulkan disharmoni antara Dewan Perwakilan Rakyat dan Presiden, yang berpotensi menyebabkan gangguan terhadap stabilitas dan efektivitas penyelenggaraan pemerintahan. Terlebih, tidak terlihat adanya peran yang signifikan dari dua kamar lain di badan legislatif yaitu Majelis Permusyawaratan Rakyat dan Dewan Perwakilan Daerah dalam memoderasi konflik antara Dewan Perwakilan Rakyat dan Presiden. Tulisan ini menggunakan pendekatan relasi legislatif dan eksekutif dalam presidensialisme multipartai serta teori sistem perwakilan untuk menggambarkan hubungan antara badan legislatif dan eksekutif di Indonesia serta memberikan alternatif solusi untuk mengembangkan relasi yang harmonis antara lembaga eksekutif dan legislatif dengan melakukan reposisi terhadap lembaga legislatif. Tulisan ini menawarkan dua alternatif reposisi: pertama, pengadopsian sistem bikameral kuat atau bikameral simetris, dan kedua, mereposisi peran Majelis Permusyawaratan Rakyat sebagai forum musyawarah tertinggi untuk merumuskan haluan negara.
\end{abstract}

Kata kunci: presidensialisme multipartai, legislatif, eksekutif, bikameral simetris

\section{EXECUTIVE-LEGISLATIVE RELATION IN INDONESIAN MULTIPARTY PRESIDENTIALISM}

\begin{abstract}
The adoption of the multiparty presidentialism in Indonesia since 2004 has caused disharmony between The House of Representative and The President, which potentially caused disruption to government stability and effectivity. Moreover, The General Assembly and The Regional Representative Council have not possesed significant role to moderate conflict between The House of Representative and The President. This paper uses the executive and legislative relation in the multiparty presidentialism approach and the assembly system theory to describe the relation between the legislative and executive body in Indonesia and give alternative solution to develop the harmony of relationship between them by reposition of The Legislative Body. This paper offers two alternatives of reposition: first, to adopt strong bicameralism or symmetric bicameralism, and second, to reposition the role of The General Assembly as the highest deliberation forum to formulate state's direction.
\end{abstract}

Key words: multiparty presidentialism, legislative, executive, symmetric bicameral

\section{PENDAHULUAN}

Efektivitas dan stabilitas penyelenggaraan pemerintahan di suatu negara ditentukan oleh optimalisasi fungsi dari berbagai institusi-institusi politik yang hadir di negara tersebut, baik oleh masing-masing institusi secara mandiri maupun dalam relasi antara institusi-institusi tersebut. Salah satu relasi yang penting untuk dijalankan secara ideal - terutama dalam rezim demokrasi - adalah relasi antara badan legislatif dan badan eksekutif. Lowell Barrington (2013:194) menyatakan, badan legislatif dan badan eksekutif adalah komponen kunci dari struktur politik suatu negara, dan salah satu karakter penting dari sistem politik adalah pembagian kekuasaan antara badan legislatif dan badan eksekutif.
Sejak dilakukannya pemilihan anggota legislatif dan pemilihan presiden secara langsung oleh rakyat pada tahun 2004, Indonesia mengadopsi sistem pemerintahan presidensial dengan sistem multipartai. Terkait dengan kehadiran partai politik di parlemen, pada tahun 2004, dari 24 partai politik yang mengikuti pemilu, terdapat 16 partai politik yang berhasil mendapatkan kursi di Dewan Perwakilan Rakyat (DPR). Pada tahun 2009, dari 32 partai politik yang mengikuti pemilu, terdapat 9 partai politik yang berhasil mendapatkan kursi di DPR. Pada tahun 2014, dari 12 partai politik yang mengikuti pemilu, terdapat 10 partai yang berhasil mendapatkan kursi di DPR (diolah dari data pada Komisi Pemilihan Umum Republik Indonesia, dalam kpu.go.id). 
Partai-partai politik yang ada di DPR terdiri dari berbagai spektrum politik. Secara umum, partai-partai politik tersebut dapat diklasifikasikan sebagai partai nasionalis (seperti Partai Demokrat, PDIP, Partai Golkar, Partai Gerindra, Partai Hanura dan PKPI), partai Islam (seperti PPP, PKS, dan PBB) dan partai yang berbasis massa Islam (seperti PAN dan PKB).

Dengan banyaknya partai politik yang ada di parlemen serta perbedaan spektrum politik, sistem pemerintahan di Indonesia saat ini dapat digolongkan sebagai sistem multipartai yang terfragmentasi kuat (a highly fragmented muliparty system) (Hanan, 2014: 30). Namun demikian, pengadopsian sistem multipartai ini ternyata tidak diikuti dengan proses institusionalisasi sistem kepartaian, yang tergambarkan dengan pola kompetisi yang labil, tidak mengakarnya hubungan antara partai politik dengan masyarakat, serta keberadaan oligarki partai (Budiatri, 2015: 50). Permasalahan semakin kompleks ketika pemerintahan yang terbentuk sejak masa pemerintahan Presiden Susilo Bambang Yudhoyono periode pertama dan kedua sampai pemerintahan Presiden Joko Widodo merupakan pemerintahan minoritas (minority goverment) oleh karena partai politik asal kedua Presiden tersebut - yaitu Partai Demokrat dan PDIP - tidak meraih suara mayoritas di DPR. Kondisi ini membuat relasi antara presiden dan DPR seringkali menjadi tidak harmonis sehingga berpotensi menghambat efektivitas dan stabilitas penyelenggaraan pemerintahan.

Kondisi sebagaimana tersebut di atas membuat presiden terpilih harus membangun koalisi partai politik pendukung pemerintah, sebagaimana lazim dilakukan di berbagai negara yang mempunyai pemerintahan minoritas. Namun demikian, koalisi partai politik tidak menjamin efektivitas dan stabilitas penyelenggaraan pemerintahan, oleh karena kalkulasi politik yang dibuat oleh partai-partai anggota koalisi acapkali membuat mereka memiliki perbedaan pandangan dengan pemerintah dalam menyikapi isu-isu tertentu atau agenda kebijakan yang diinisiasi oleh pemerintah. Selain itu, praktik politik pragmatis atau politik transaksional membuat partai-partai seringkali menghitung insentif politik jangka pendek yang tidak hanya mengganggu efektivitas dan stabilitas penyelenggaraan pemerintahan namun juga bertentangan dengan kepentingan atau aspirasi publik.

Dalam situasi seperti ini, sejatinya kamar lain pada lembaga legislatif yaitu Majelis Permusyawaratan Rakyat (MPR) dan Dewan Perwakilan Daerah (DPD) dapat menjalankan peran untuk menjaga keharmonisan relasi antara badan legislatif dan badan eksekutif, sekaligus meminimalisir praktik-praktik politik transaksional antara kedua badan tersebut. Namun demikian, terdapat beberapa kendala yang dihadapi oleh MPR dan DPD untuk dapat melakukan peran tersebut. Tulisan ini akan mencermati beberapa hambatan serta keterbatasan kelembagaan yang dimiliki oleh MPR dan DPD dan merekomendasikan beberapa alternatif upaya reposisi badan legislatif. Hal tersebut diperlukan untuk mendorong terjalinnya relasi yang harmonis antara badan legislatif dan eksekutif dalam presidensialisme multipartai di Indonesia, yang bertujuan untuk menciptakan efektivitas dan stabilitas penyelenggaraan pemerintahan.

\section{METODE}

Penelitian yang dilakukan terhadap relasi antara lembaga eksekutif dan legislatif memerlukan identifikasi dan pemahaman yang mendalam untuk melihat konteks peristiwa politikyang melingkupi permasalahan penelitian dan proses yang terjadi dalam relasi antara lembaga eksekutif dan legislatif. Oleh karena itu, penelitian yang digunakan adalah penelitian kualitatif dengan menggunakan studi literatur. Sebagaimana dikemukakan oleh Joseph A. Maxwell (1996:17-19), penelitian kualitatif antara lain ditujukan untuk memahami makna, memahami konteks partikular, mengantisipasi fenomena dan pengaruh yang tidak terantisipasi, serta memahami proses.

Penelitian ini akan mengidentifikasi problematika yang ditimbulkan dalam relasi antara lembaga eksekutif dan legislatif dalam presidensialisme multipartai. Penelitian ini juga akan mengidentifikasi problematika internal lembaga legislatif, dimana terjadi ketidak seimbangan kewenangan yang dimiliki oleh kamar-kamar di dalam lembaga legislatif. Selanjutnya, penelitian ini akan memberikan rekomendasi berupa alternatif reposisi terhadap lembaga legislatif yang ditujukan untuk 
mengharmoniskan relasi antara lembaga legislatif dan eksekutif agar penyelenggaraan pemerintahan dapat berjalan dengan efektif dan stabil.

\section{HASIL DAN PEMBAHASAN}

Kombinasi antara sistem pemerintahan presidensial dan sistem multipartai yang diadopsi secara bersamaan di suatu negara telah menjadi salah satu fokus penelitian para ahli dalam kajian perbandingan politik. Terdapat beberapa peristilahan yang digunakan oleh para ahli politik untuk mendefinisikan kombinasi tersebut. Scott Mainwaring (1989:2) menggunakan istilah multiparty presidential democracy untuk menjelaskan kombinasi antara presidensialisme dan sistem multipartai dalam negara-negara demokrasi. Dalam tulisan selanjutnya, Mainwaring (1993:222) menggunakan istilah multiparty presidential system ketika menjelaskan kombinasi antara sistem presidensial dengan sistem multipartai. Carlos Pereira dan Marcus Andre Melo (2012:156) menggunakan istilah multiparty presidential regime dan multiparty presidentialism, untuk menggambarkan suatu rezim presidensial yang memiliki banyak fragmentasi partisan pada lembaga legislatif. Eric D. Raile, Carlos Pereira, dan Timothy J. Power (2010:1) menggunakan istilah multiparty presidentialism ketika membahas tentang dukungan legislatif terhadap eksekutif dalam rezim presidensial dengan sistem multipartai. Djayadi Hanan (2014) menggunakan istilah sistem presidensial multipartai dan presidensialisme multipartai secara bergantian dalam pembahasan tentang relasi legislatif dan eksekutif di Indonesia pasca pengadopsian sistem presidensial dan sistem multipartai.

Terdapat beberapa studi tentang sistem pemerintahan presidensial yang menunjukkan situasi dimana sistem presidensial justru menimbulkan ketidakstabilan sistem politik. Studi yang dilakukan Juan J. Linz (1990:52) pada negara-negara Amerika Latin mengungkapkan bahwa apabila dibandingkan dengan rezim presidensial, rezim parlementer lebih kondusif bagi pembentukan demokrasi yang stabil terutama di negara-negara yang mempunyai banyak partai politik serta fragmentasi atau pembelahan politik yang mendalam (deep political cleavages). Scott
Mainwaring (1993: 200-201) menambahkan variabel sistem kepartaian sebagai faktor yang menyebabkan ketidakstabilan sistem presidensial. Menurutnya, kombinasi antara sistem presidensial dan sistem multipartai mengandung problematika karena terdapat kecenderungan terjadinya kebuntuan (deadlock) dan kelumpuhan (immobilism) dalam relasi antara eksekutif dan legislatif, ditambah dengan polarisasi ideologis serta sulitnya membangun koalisi antar partai.

Salah satu faktor yang seringkali dikaitkan dengan problematika sistem presidensial adalah pembentukan koalisi. Menurut Mainwaring (1993: 201), dalam sistem presidensial pembentukan koalisi cenderung menjadi masalah oleh karena perbedaan pandangan tentang bagaimana kekuasaan eksekutif dibangun dan dipertahankan. Selain itu, kemungkinan terjadinya perpecahan dalam koalisi lebih besar apabila dibandingkan dengan sistem parlementer, oleh karena dalam sistem presidensial multipartai para pemimpin partai seringkali merasakan kebutuhan untuk menjaga jarak dengan presiden. Hal itu dilakukan oleh karena dengan menjadi partner dalam koalisi pemerintahan, para pemimpin partai khawatir partainya akan kehilangan identitas, terkena getah akibat kesalahan yang dilakukan pemerintah, dan tidak mendapatkan keuntungan apabila pemerintah melakukan kinerja yang baik (1993:222).

Dalam praktik presidensialisme multipartai di Indonesia, potensi terganggunya efektivitas dan stabilitas penyelenggaraan pemerintahan terlihat sejak masa pemerintahan Presiden Susilo Bambang Yudhoyono. Tiga pemerintahan yang terpilih sejak pengadopsian presidensialisme multipartai (pemerintahan Presiden Susilo Bambang Yudhoyono periode pertama dan kedua serta pemerintahan Presiden Joko Widodo) memperlihatkan pasang surut relasi antara badan legislatif dan badan eksekutif sebagai konsekuensi dari munculnya pemerintahan minoritas (minority government) yangtidakmendapatkandukunganmayoritasdari parlemen. Pada periode pertama pemerintahan Presiden Susilo Bambang Yudhoyono, Partai Demokrat sebagai partai pemerintah (the ruling party) hanya menguasai 57 kursi (10,36\%) dari keseluruhan kursi di DPR. Demikian pula pada periode kedua pemerintahan Presiden Susilo Bambang Yudhoyono, Partai Demokrat hanya 
menguasai 150 (20,81\%) kursi di DPR. Pada pemerintahan Presiden Joko Widodo, PDIP hanya menguasai 109 (19,46\%) kursi di DPR (diolah dari data pada Komisi Pemilihan Umum Republik Indonesia, dalam kpu.go.id).

Langkah yang diambil untuk menambah dukungan di parlemen adalah dengan membentuk koalisi partai politik pendukung pemerintah. Pada pemerintahan Presiden Susilo Bambang Yudhoyono periode pertama, dibentuk koalisi yang beranggotakan Partai Demokrat, Partai Golkar, PPP, PKB, PAN, PKS, PBB dan PKPI yang menguasai 403 $(73,5 \%)$ kursi di DPR. Pada pemerintahan Presiden Susilo Bambang Yudhoyono periode kedua, dibentuk koalisi yang beranggotakan Partai Demokrat, Partai Golkar, PKS, PAN, PPP dan PKB yang menguasai 423 (75,54\%) kursi di DPR. Pada pemerintahan Presiden Joko Widodo, pada awalnya dibentuk koalisi yang beranggotakan PDIP, PKB, Nasdem dan Hanura yang menguasai 207 (36,96\%) kursi di DPR. Selanjutnya anggota koalisi bertambah dengan bergabungnya PPP, PAN dan Partai Golkar sehingga dukungan di DPR menjadi 386 (68,93\%) kursi (diolah dari data pada Komisi Pemilihan Umum Republik Indonesia, dalam kpu.go.id). Namun demikian, pembentukan koalisi partai-partai politik pendukung pemerintah - yang secara kuantitas telah menguasai mayoritas kursi di DPR ternyata seringkali tidak mampu memberikan jaminan terhadap efektivitas dan stabilitas penyelenggaraan pemerintahan.

Ketiadaanjaminanterhadap efektivitasdan stabilitas pemerintahan terlihat pada beberapa peristiwa politk pada masa pemerintahan Presiden Susilo Bambang Yudhoyono dan Presiden Joko Widodo. Pada pemerintahan Presiden Susilo Bambang Yudhoyono periode 2004-2009, ketiadaan jaminan anggota koalisi untuk mendukung pemerintah antara lain dapat dilihat dari pengajuan empat hak interpelasi dan dua hak angket yang ditujukan kepada pemerintah dan disetujui oleh mayoritas fraksi di DPR termasuk fraksi-fraksi yang merupakan perpanjangan tangan dan partai-partai yang tergabung dalam koalisi pendukung pemerintah (Harris, 2004: 8-11). Pada pemerintahan Presiden Susilo Bambang Yudhoyono periode 2009-2014, ketidaksolidan anggota koalisi dalam mendukung pemerintah kembali terlihat, sebagai contoh beberapa partai politik anggota koalisi ikut menyetujui usulan penggunaan hak angket tentang bailout Bank Century pada tahun 2009. Ketiadaan jaminan dukungan anggota koalisi terhadap pemerintahan kembali tampak dalam Pemerintahan Presiden Joko Widodo, misalnya dalam kasus pengangkatan Kapolri dimana para anggota koalisi menunjukkan resistensi terhadap keputusan Presiden Joko Widodo untuk menarik pencalonan Komisaris Jenderal Budi Gunawan sebagai Kapolri.

Peristiwa-peristiwa tersebut di atas dapat mengganggu efektivitas penyelenggaraan pemerintahan, oleh karena lembaga eksekutif memerlukan dukungan dari lembaga legislatif agar pengelolaan pemerintahan dapat berjalan dengan lancar. Berbagai agenda kebijakan dan program pemerintah dapat berjalan apabila didukung oleh anggaran yang memadai, dan persetujuan terhadap pengalokasian dan penggunaan anggaran berada di tangan DPR. Selain itu, ketiadaan dukungan politik dari lembaga legislatif terhadap lembaga eksekutif dapat menimbulkan instabilitas politik, ketika kekuatan-kekuatan politik mayoritas di lembaga legislatif secara simultan menunjukkan perbedaan pandangan dengan berbagai kebijakan yang diinisiasi oleh lembaga eksekutif. Situasi tersebut pada akhirnya akan menghambat pencapaian agenda-agenda pembangunan nasional.

Dalam kondisi seperti ini, maka MPR dan DPD merupakan unsur badan legislatif seharusnya dapat memainkan peran untuk meminimalisir potensi ketidakharmonisan hubungan antara Presiden dan DPR dalam sistem presidensial multipartai, oleh karena relasi antara presiden dan badan perwakilan sejatinya tidak hanya berupa relasi antara presiden dan DPR namun juga terkait dengan keberadaan kamar lain pada lembaga legislatif. Namun demikian peran lembagalembaga tersebut akan sangat ditentukan oleh sistem perwakilan yang diadopsi pasca amandemen UUD 1945 serta kewenangan yang dimiliki oleh masing-masing lembaga dalam sistem perwakilan tersebut yaitu MPR, DPR, dan DPD.

Pasca kejatuhan rezim Orde Baru pada tahun 1998, terjadi proses transisi demokrasi yang ditandai antara lain dengan dilakukannya reformasi konstitusi. Reformasi konstitusi tersebut juga dilakukan terhadap kelembagaan dan fungsi yang dijalankan oleh MPR. Valina 
Singka Subekti (2008:189) mengungkapkan, salah satu masalah utama yang diputuskan untuk dibahas dalam perubahan UUD 1945 pada Sidang Umum MPR tahun 1999 adalah pemberdayaan MPR dan DPR.

Amandemen UUD 1945 mengubah beberapa ketentuan mengenai MPR. Amandemen Ketiga UUD 1945 yang dilakukan pada tahun 2001 mengatur kewenangan MPR yang dirumuskan dalam Pasal 3 UUD 1945. Pasal tersebut menyatakan bahwa kewenangan MPR adalah mengubah dan menetapkan UUD, melantik Presiden dan/atau Wakil Presiden, dan memberhentikan Presiden dan/atau Wakil Presiden. Amandemen Keempat UUD 1945 yang dilakukan pada tahun 2002 mengatur tentang keanggotaan MPR yang dirumuskan dalam Pasal 2 UUD 1945. Pasal tersebut menyatakan bahwa MPR terdiri dari anggota DPR dan anggota DPR yang dipilih melalui pemilihan umum.

Berdasarkan Pasal 2 ayat 1 UUD 1945 pasca amandemen, secara kelembagaan MPR menjadi lembaga negara yang anggotanya terdiri dari anggota DPR dan anggota DPD. Amandemen UUD 1945 dengan demikian berkonsekuensi terhadap perubahan struktur kelembagaan MPR. Keanggotaan MPR berdasarkan UUD 1945 sebelum amandemen terdiri dari anggota DPR, utusan golongan dan utusan daerah. Rekruitmen anggota DPR berasal dari pemilihan umum, sedangkan rekruitmen utusan golongan dan utusan daerah dilakukan melalui pengangkatan oleh Presiden. Keanggotaan MPR berdasarkan UUD 1945 pasca amandemen terdiri dari DPR dan DPD. DPD merupakan lembaga negara baru yang digagas untuk mengakomodasi keterwakilan daerah-daerah. Namun demikian, berbeda dengan utusan daerah yang diangkat oleh Presiden, rekruitmen anggota DPD dilakukan melalui pemilihan.

Pada saat pembahasan amandemen UUD 1945 yang dilakukan oleh Badan Pekerja MPR, fraksi-fraksi menyepakati untuk membentuk kamar lain selain DPR sebagai unsur pembentuk MPR. Namun demikian, terdapat dua pandangan mengenai struktur kelembagaan MPR. Pandangan pertama berpendapat bahwa MPR terdiri dari anggota DPR dan anggota DPD, sehingga menimbulkan konsekuensi munculnya lembaga legislatif ketiga yaitu MPR yang menjadi lembaga permanen. Pandangan kedua berpendapat bahwa MPR terdiri dari DPR dan DPD. Pandangan ini menghendaki terbentuknya sistem lembaga perwakilan dua kamar dan tidak menghendaki MPR menjadi lembaga permanen (Isra, 2010: 240-241).

Rumusan UUD 1945 pasca amandemen akhirnya menetapkan bahwa MPR terdiri dari anggota DPR dan anggota DPD. Sebagai konsekuensinya, beberapa ahli menyatakan bahwa Indonesia tidak mengadopsi sistem perwakilan dua kamar (bicameral system) dimana terdapat dua lembaga yang merupakan lembaga perwakilan di suatu negara, melainkan menerapkan sistem tiga kamar (threecameral system) (Isra: 2010: 254). MPR menjadi wadah badan perwakilan tersendiri karena susunannya yang menyebutkan terdiri dari anggota-anggota DPR dan DPD, padahal dalam sistem bikameral yang menjadi unsur bukan anggota melainkan badan yaitu DPR dan DPD. Apabila anggota yang menjadi unsur, maka MPR merupakan badan yang berdiri sendiri. Selain itu, MPR tetap memiliki kewenangan tersendiri yang berbeda dengan kewenangan DPR dan DPD (Manan, 2003: 75). Dengan demikian, Indonesia mempunyai tiga kamar dalam lembaga perwakilan yaitu MPR, DPR, dan DPD.

Terkait dengan kewenangan MPR, apabila dibandingkan dengan kewenangan yang dimiliki oleh MPR sebelum dilakukan amandemen terhadap UUD 1945, terjadi proses reduksi kewenangan terhadap fungsi yang dijalankan oleh MPR. MPR tidak lagi menjadi lembaga tertinggi negara, melainkan menjadi lembaga negara yang mempunyai kedudukan sejajar dengan lembaga-lembaga negara lainnya. MPR tidak lagi merumuskan haluan negara yang wajib dijalankan oleh Presiden, dan juga tidak lagi memiliki kewenangan untuk memilih Presiden dan/atau Wakil Presiden.

Penerapan sistem perwakilan tiga kamar di Indonesia menimbulkan problematika oleh karena fokus kewenangan badan legislatif berada di DPR. MPR hanya mempunyai kewenangan untuk mengubah dan menetapkan UUD, melantik Presiden dan/atau Wakil Presiden, serta memberhentikan Presiden dan/ atau Wakil Presiden (Pasal 3 UUD 1945). Selain itu, berdasarkan UU No. 17 Tahun 2014 tentang MPR, DPR, DPD dan DPRD, MPR mempunyai kewenangan memilih Presiden dan/atau Wakil Presiden apabila ditengah masa 
jabatan terjadi kekosongan jabatan.

Sistem politik pasca amandemen UUD 1945 nampak memfokuskan kewenangan badan legislatif pada DPR. Menurut Pasal 20A ayat 1 UUD 1945, DPR menjalankan fungsi legislasi, fungsi anggaran, dan fungsi pengawasan. Pasal 20 ayat 1 UUD 1945 bahkan menyatakan bahwa kekuasaan membentuk undang-undang berada di tangan DPR. Selain kewenangan tersebut di atas, UU No. 17 Tahun 2014 mengamanatkan beberapa kewenangan lain yang dimiliki oleh DPR yaitu pemberian persetujuan kepada Presiden untuk menyatakan perang dan membuat perdamaian dengan negara lain, pemberian persetujuan atas perjanjian internasional tertentu, pemberian pertimbangan kepada Presiden dalam pemberian amnesti dan abolisi, pemberian pertimbangan kepada Presiden dalam hal pengangkatan duta besar dan penerimaan penempatan duta besar negara lain, pemilihan anggota BPK, pemberian persetujuan kepada Presiden atas pengangkatan dan pemberhentian anggota Komisi Yudisial, pemberian persetujuan calon hakim agung, pemilihan tiga orang hakim konstitusi. Selain itu juga terdapat kewenangan untuk memilih atau mengkonfirmasi beberapa jabatan publik, antara lain jabatan komisioner lembagalembaga negara, Panglima TNI dan Kapolri.

Di sisi lain, kewenangan yang diberikan kepada DPD sangat kecil, bahkan DPD sejatinya tidak memiliki kewenangan tersendiri (original power) sehingga tidak dapat menjalankan fungsinya secara optimal. Dalam fungsi legislasi, DPD tidak tidak dapat menjalankan fungsinya secara utuh karena DPD hanya mengikuti proses pembentukan UU di awal namun keputusan menyetujui RUU menjadi UU sepenuhnya dilakukan oleh DPR. Dalam fungsi deliberasi, DPD tidak dapat menjalankan fungsinya secara optimal karena pertimbangan yang diberikan oleh DPD tidak bersifat mengikat terhadap DPR. Terkait fungsi pemeriksaan/penelitian, DPD juga tidak dapat menjalankan fungsinya secara optimal oleh karena DPD tidak memiliki instrumen untuk menindaklanjuti melainkan hanya menyerahkan hasil pemeriksaan/penelitian tersebut kepada DPR (Manan, 2015: 60). Demikian pula dengan kewenangan MPR yang mengalami reduksi apabila dibandingkan dengan periode sebelum amandemen UUD 1945 sebagaimana telah dijelaskan di atas.

Saldi Isra (2004: 128) menyatakan bahwa amandemen UUD 1945 telah menyebabkan terjadinya pergeseran dari konstitusi yang semula didominasi oleh kewenangan eksekutif (executive-heavy constitution) menjadi konstusi yang didominasi oleh kewenangan DPR (DPR-heavy constitution). Pandangan tersebut disepakati oleh Denny Indrayana (2008: 364), yang menyatakan bahwa terdapat ketimpangan kewenangan yang dimiliki oleh DPR dan DPD, dimana DPD memiliki kewenangan yang lebih sedikit dibandingkan dengan DPR. M. Yunus Wahid (2011:21) menilai terdapat disproporsionalitas dari segi kewenangan DPR dan DPD dalam UUD 1945 pasca amandemen. DPR mempunyai kekuasaan sangat besar yang mencakup kekuasaan legislatif dan kekuasan non-legislatif, sementara DPD hanya memiliki kewenangan yang sangat terbatas dan bersifat semu.

Fokus kewenangan badan legislatif yang dititkberatkan pada DPR membuat relasi antara badan legislatif dan badan eksekutif sangat ditentukan oleh relasi antara DPR dan Presiden. Dalam praktik presidensial multipartai di Indonesia, pola relasi seperti ini rentan mengakibatkan terjadinya konflik antara DPR dan Presiden karena DPR merupakan institusi yang diisi oleh perwakilan partaipartai politik, dimana mayoritas kekuatan politik tersebut tidak memberikan dukungan penuh kepada pemerintah.

Problematika lain yang menyebabkan timbulnya potensi konflik antara Presiden dengan kekuatan-kekuatan politik yang ada di DPR adalah berkembangnya praktik politik pragmatis atau politik transaksional demi kepentingan jangka pendek. Asrinaldi mengungkapkan bahwa Presiden tersandera oleh misi partai politik yang tergabung dalam koalisi pendukung pemerintah sehingga Presiden tidak dapat bertindak secara otonom. Bahkan menurut Asrinaldi, kondisi tersebut menjadikan Indonesia tidak mempraktikkan sistem presidensial secara sempurna karena adanya praktik koalisi model parlementer (2013: 75).

Hanta Yudha (2010:173 menyatakan bahwa koalisi partai pasca Pemilu 2004 dibangun di atas kepentingan pragmatisme politik kekuasaan, bukan didasarkan atas 
kedekatan ideologi atau persamaan platform, sehingga pola koalisi menjadi sangat cair, rapuh dan pragmatis. Kuskrido Ambardi (2009: 250-282) mengungkapkan hal serupa, dengan menyatakan bahwa meskipun pada pertarungan pemilihan presiden tahun 2004 terdapat peluang untuk terbentuknya koalisi berbasis ideologi dan koalisi kemenanganminimal, namun pasca pemilihan presiden partai-partai membuang ideologi mereka untuk bergabung dengan pemerintahan dan menciptakan koalisi turah (oversized coalition) yang membentuk dan memelihara praktik kartelisasi. Koalisi dengan demikian telah digunakan oleh partai-partai politik untuk mengembangkan sistem kepartaian yang terkartelisasi, yang diikat oleh kepentingan kolektif partai-partai dalam menjaga sumbersumber rente di lembaga eksekutif dan legislatif demi keberlangsungan hidup partai-partai yang bersangkutan (2009: 347). Dan Slater (2004: 66) secara lebih jauh mengungkapkan bahwa praktik partai kartel pada masa pemerintahan Presiden Abdurrahman Wahid dan Megawati Soekarnoputri menemukan bentuknya yang terutama terjadi dalam pengisian jabatan di kabinet, dimana kabinet menjadi jembatan emas yang menghubungkan parlemen dan lembaga kepresidenan, yang menyediakan bagi sedikit orang yang beruntung akses kepada sumber-sumber patronase yang berlimpah dari lembaga eksekutif. Semua posisi kabinet menyediakan peluang patronase yang lebih besar daripada kursi-kursi parlemen yang tidak memiliki keistimewaan.

Praktik politik pragmatis atau politik transaksional tersebut tentu tidak membawa kebermanfaatan terhadap kepentingan publik. Selain itu, politik transaksional berpotensi menimbulkan konflik antara badan legislatif dan badan eksekutif karena relatif mudahnya terjadi perbedaan atau pertentangan antara kekuatankekuatan politik yang ada di badan legislatif dan badan eksekutif akibat berubahnya kepentingan jangka pendek di antara mereka. Dengan demikian, diperlukan upaya kelembagaan untuk meminimalisir praktek-praktek penyimpangan tersebut. Upaya tersebut dapat dilakukan dengan melakukan reposisi terhadap kelembagaan MPR dan DPD untuk mengelola dan memoderasi potensi konflik dalam relasi antara badan legislatif dan badan eksekutif.

Kerentanan relasi antara Presiden danDPR yang berpotensi menimbulkan inefektivitas dan instabilitas penyelenggaraanpemerintahan dapat diminimalisir dengan mengoptimalisasikan peran MPR melalui reposisi kedudukan MPR. Terdapat tiga alternatif solusi yang dapat ditawarkan terkait upaya reposisi kedudukan MPR. Pertama, mengembalikan kedudukan MPR sebagai lembaga tertinggi negara yang memegang kekuasaan tertinggi sebagaimana ketentuan di dalam UUD 1945 sebelum dilakukan amandemen. Kedua, mengubah sistem perwakilan menjadi sistem bikameral yang kuat atau simetris (strong/symmetric bicameral system) dengan menjadikan DPR dan DPD sebagai kamar-kamar yang mempunyai kewenangan relatif setara danmeniadakan keberadaan MPR sebagai salah satu kamar dalam badan legislatif. Ketiga, mereposisi kedudukan MPR sebagai forum permusyawaratan tertinggi dalam negara tanpa mengembalikan MPR menjadi pemegang kekuasaan tertinggi atau menghilangkan kedudukan MPR salah satu kamar dalam badan legislatif.

\section{Mengembalikan Kedudukan Majelis Per- musyawaratan Rakyat Sebagai Lembaga Tertinggi Negara}

Secara teoretik, potensi konflik antara badan legislatif dan badan eksekutif dapat diminimalisir apabila kedua lembaga tidak memiliki sumber legitimasi yang independen (independent legitimacy) atau dengan meniadakan adanya legitimasi ganda (dual legitimacy). Hal tersebut dapat dilakukan apabila legitimasi yang didapat dari rakyat berasal dari pemilihan anggota-anggota badan legislatif, sementara badan eksekutif dibentuk oleh badan legislatif. Dalam kondisi ini, sumber legitimasi kedua lembaga menjadi terbagi (shared legitimacy).

Apabila rakyat hanya memilih anggota legislatif, maka kekuasaan akan berada di tangan badan legislatif(supremacy of legislature or supremacy of parliament) karena badan legislatif bertanggung jawab secara langsung kepada badan legislatif sebagai konsekuensi pembentukan badan eksekutif oleh badan legislatif. Badan eksekutif tidak bertanggung jawab secara langsung kepada rakyat karena rakyat tidak secara langsung memilih kepala badan eksekutif, dengan katalainbadan eksekutif tidak mendapatkan legitimasi yang independen. Konstruksi relasi antara badan legislatif dan badan eksekutif seperti ini terbangun dalam 
sistem pemerintahan parlementer. Sebagaimana dinyatakan oleh Douglas Verney (dalam Lijphart, 1992: 36), dalam sistem parlementer bada eksekutif bertanggung jawab secara politik kepada badan legislatif. Apabila badan legislatif menilai badan eksekutif bertindak tidak bijak atau tidak konstitusional, maka badan legislatif dapat mengeluarkan mosi tidak percaya atau tidak memberikan persetujuan terhadap usulan penting dari badan eksekutif, dalam rangka mendorong pemerintah untuk mengundurkan diri sehingga kepala negara dapat menunjuk pemerintahan yang baru. Dengan kata lain, karakter sistem parlementer adalah adanya supremasi parlemen, dan parlemen merupakan fokus kekuasaan dalam sistem politik (dalam Lijphart, 1992: 37-38).

Oleh karena kekuasaan tertinggi berada di tangan badan legislatif, potensi konflik yang berlangsung secara terus menerus antara badan legislatif dan badan eksekutif dan bermuara pada inefektivitas dan instabilitas penyelenggaraan pemerintahan dapat dihindari oleh karena badan legislatif setiap saat dapat menjatuhkan badan eksekutif untuk kembali mencari keseimbangan politik baru. Di sisi lain, kerangka sistem parlementer lazimnya juga memberikan kewenangan kepada kepala badan eksekutif untuk dapat membubarkan badan legislatif dengan alasan yang sama dan menjadwalkan pelaksanaan pemilihan umum baru, misalnya ketika terjadi perpecahan diantara partai-partai anggota koalisi pemerintah.

Konstruksi MPR sebelum dilakukannya amandemen memenuhi kriteria sumber legitimasi yang terbagi (shared legitimacy) antara badan legislatif dan badan eksekutif. Hal ini dikarenakan rakyat hanya memilih anggota DPR, sementara presiden dan wakil presiden dipilih oleh MPR dimana sebagian anggota MPR merupakan anggota DPR. Dengan demikian, presiden bertanggung jawab kepada MPR dan MPR menjadi badan yang memegang kekuasan tertinggi dalam negara.

Namun demikian, terdapat beberapa problematika apabila alternatif solusi yang dipilih untuk memperkuat kelembagaan MPR adalah dengan mengembalikan kedudukan MPR sebagaimana diatur di dalam UUD 1945 sebelum amandemen. Pertama, kedudukan MPR sebagai pemegang kekuasaan tertinggi dengankekuasaan yang tidak terbatas menyalahi prinsip demokrasi. Salah satu prinsip utama dari demokrasi adalah adanya pembatasan kekuasaan terhadap institusi-institusi politik yang menyelenggarakan kekuasaan negara. Pembatasan kekuasaan itu biasanya diiringi dengan kehadiran sistem pengawasan dan pengimbangan (checks and balances system) oleh institusi politik lain. Kekuasaan yang tidak dibatasi memiliki kecenderungan untuk diselewengkan. Terlebih, sejarah politik negara Indonesia pada masa Demokrasi Terpimpin serta masa Orde Baru menunjukkan berbagai penyimpangan yang dilakukan oleh penguasa dengan memanfaatkan kewenangan MPR sebagai lembaga tertinggi negara. Beberapa contoh penyimpangan antara lain adalah ketika MPR melalui Dekrit MPR No. III Tahun 1963 mengangkat Presiden Soekarno menjadi presiden seumur hidup (Indrayana, 2008: 111). Demikian pula pada masa Orde Baru, dimana dalam prakteknya mayoritas anggota MPR tidak dipilih melainkan diangkat oleh Presiden Soeharto. Dominasi Presiden Soeharto terhadap MPR menyebabkan kekuasaan konstitusional MPR untuk mengontrol Presiden atau untuk memilih kandidat presiden alternatif tidak pernah terjadi (Indrayana, 2008: 118-119).

Kedua, hambatan untuk mengubah sistem pemilihan presiden dan wakil presiden yang berdasarkan UUD 1945 pasca amandemen dipilih secara langsung oleh rakyat. Gagasan untuk menerapkan dan memperkuat sistem presidensial yang salah satu karakteristiknya adalah melalui pemilihan kepala badan eksekutif secara langsung oleh rakyat telah menjadi kesepakatan para anggota MPR yang melakukan amandemen UUD 1945. Selain itu, pemilihan presiden dan wakil presiden secara langsung oleh rakyat dipandang sebagai perwujudan kedaulatan rakyat untuk menentukan pimpinan negara. Apabila terdapat upaya untuk mengembalikan kedudukan MPR sebagai lembaga tertinggi negara, maka akan muncul resistensi publik karena upaya tersebut akan dipersepsikan sebagai cara untuk mengembalikan praktik-praktik non-demokratis sebelum dilakukannya amandemen UUD 1945.

Resistensi publik terhadap upaya mengembalikan pola pemilihan langsung menjadi pola pemilihan dengan perwakilan ini misalnya terjadi dalam pemilihan kepala daerah. Pemilihan kepala daerah yang telah beberapa lama dilaksanakan melalui sistem pemilihan langsung, diubah mekanismenya 
melalui UU No. 22 Tahun 2014 dengan sistem pemilihan melalui DPRD. Pengaturan tersebut segera menimbulkan resistensi publik, sehingga pada akhirnya Presiden Susilo Bambang Yudhoyono mengeluarkan Peraturan Pemerintah Penggganti Undang-Undang untuk mengembalikan mekanisme pemilihan kepala daerah menjadi pemilihan langsung oleh rakyat. Pengalaman tersebut di atas menunjukkan bahwa terdapat kesulitan apabila terdapat upaya untuk mengembalikan mekanisme pemilihan menjadi pemilihan melalui perwakilan, termasuk di dalamnya pemilihan presiden dan wakil presiden. Hal tersebut akan memicu sentimen negatif publik karena mekanisme pemilihan melalui perwakilan dipandang tidak sejalan dengan upaya membangun sistem demokrasi, bahkan dapat dilihat sebagai upaya untuk mengembalikan Indonesia ke dalam sistem otoritarianisme.

Ketiga, upaya mengembalikan UUD 1945 ke dalam kondisi sebelum amandemen akan menimbulkan resistensi karena dapat dipersepsikan sebagai upaya non-demokratis yang mencederai amanat reformasi politik. Selain itu, penerapan kembali UUD 1945 sebelumamandemenakanmenimbulkan banyak komplikasi politik dan menghidupkan kembali ketentuan-ketentuan yang bertentangan dengan prinsip-prinsip demokrasi, misalnya ketentuan yang tidak mengatur pembatasan masa jabatan presiden, dan kekuasaan membentuk undangundang yang ada di tangan presiden. Demikian juga dengan ketentuan-ketentuan di dalam UUD 1945 sebelum amandemen yang memunculkan dominasi kewenangan eksekutif (executiveheavy constitution) yang ditenggarai menjadi salah-satu penyebab praktik otoritarianisme di Indonesia pada masa Orde Baru.

\section{Pengadopsian Sistem Bikameralisme Kuat atau Bikameralisme Simetris (Strong Bicameralism or Symmetric Bicameralism)}

Pengadopsian sistem perwakilan tiga kamar (trikameral) di Indonesia yang menitikberatkan kewenangan badan legislatif di DPR ditenggarai menjadi salah satu faktor pemicu munculnya potensi konflik antara badan legislatif dan badan eksekutif serta terbangunnya praktik politik transaksional yang mengedepankan kepentingan jangka pendek demi keuntungan kelompokkelompok tertentu. Ketiadaan mekanisme pengawasan dan pengimbangan (checks and balances mechanism) di dalam badan legislatif membuat
DPR menjadi hegemonik apabila dibandingkan dengan MPR dan DPD. Perubahan sistem perwakilan dengan demikian dapat menjadi jalan keluar untuk mengeliminasi karakter hegemonik DPR terhadap unsur badan legislatif yang lain.

Terkait dengan pengadopsian bikameralisme di Indonesia, sebenarnya gagasan untuk menerapkan sistem tersebut telah dibahas dalam proses amandemen UUD 1945 pada Sidang Umum MPR tahun 1999. Pada saat itu, muncul perdebatan terkait usulan mengenai pembentukan DPD. Fraksi Partai Golkar mengusulkan pembentukan DPD dengan kewenangan legislasi yang sejajar dengan DPR. Namun demikian, usulan ini ditentang oleh Fraksi PDIP yang tidak menyetujui pembentukan DPD dalam bingkai sistem bikameralisme. Fraksifraksi lain kemudian mengusulkan alternatif yaitu dengan pemberian kewenangan legislasi yang terbatas kepada DPD. Pada akhirnya, fraksi-fraksi menyetujui pembentukan DPD dengan kewenangan legislasi yang terbatas (Subekti, 2008: 221-222).

Samuel C. Patterson dan Anthony Mughan (1993: 3) mengungkapkan, sebagian besar parlemen di dunia mengadopsi sistem unikameral. Namun demikian, sistem unikameral tersebut diterapkan pada negara-negara yang relatif kecil, termasuk pada level subnasional. Pada negara-negara yang lebih besar, terdapat kecenderungan parlemen bikameral, yang terdiri dari senates dan houses of representatives.

Upaya mengimbangi kewenangan DPR dapat dilakukan dengan mengadopsi sistem perwakilan dua kamar (bikameral). Melalui sistem perwakilan ini, kedua kamar dalam badan legislatif dapat melakukan mekanisme pengawasan dan pengimbangan secara internal (internal checks and balances), sehingga praktik-praktik menyimpang dapat dieleminasi. Selain itu, badan eksekutif mempunyai pilihan untuk membangun relasi politik dengan kedua kamar dalam badan legislatif. Sebagaimana dinyatakan oleh Samuel C. Patterson dan Anthony Mughan (1993: 9) kehadiran kamar kedua dalam badan legislatif selain memberikan peluang adanya perbedaan representasi, juga menyediakan proses pengulangan dalam pembuatan kebijakan untuk mencegah terjadinya kesalahan, dan menunda pembuatan keputusan sehingga dicapai konsensus diantara pandanganpandangan yang berbeda (redundancy). Kriteria redundancy ini tiada lain merupakan 
manifestasi dari mekanisme pengawasan dan pengimbangan secara internal di dalam badan legislatif.

Keberadaan DPD sebagai salah satu kamar dalam parlemen Indonesia saat ini hanyalah memenuhi kriteria perbedaan representasi. DPD merupakan representasi yang menunjukkan perbedaan teritorial dengan basis pemilihan di wilayah propinsi. Satu wilayah propinsi di Indonesia diwakili oleh empat orang anggota DPD, yang dipilih melalui sistem distrik berwakil banyak (single non-trasferable vote). Namun kriteria redundancy tidak terpenuhi, karena DPD tidak menjadi kamar yang memiliki kewenangan untuk melakukan proses pengulangan dalam pembuatan kebijakan atau penundaan pembuatan keputusan. Padahal, kewenangan ini penting dalam rangka membangun mekanisme pengawasan dan pengimbangan secara internal di dalam badan perwakilan. Apabila DPD mempunyai kewenangan yang bersifat redundancy, maka hegemoni DPR pada badan legislatif dapat diminimalisiri karena terdapat pengimbangan yang dilakukan oleh DPD. Bahkan dalam konteks potensi konflik antara legislatif dan eksekutif, DPD dapat menjalankan fungsi moderasi terhadap potensi konflik antara DPR dan Presiden. Oleh karenanya, pemberian kewenangan yang bersifat redundancy kepada DPR dalam rangka menciptakan mekanisme pengawasan dan pengimbangan secara internal menjadi salah satu alternatif yang perlu dipertimbangkan.

Terkait dengan sistem bikameralisme yang ideal untuk diterapkan di Indonesia, terdapat tiga alternatif sistem bikameralisme yang dapat dipilih untuk diadopsi oleh lembaga perwakilan di Indonesia. Pertama adalah bikameralisme asimetris atau bikameralisme lemah (asymmetric bicameralism/ weak bicameralism/ soft bicameralism) dimana kewenangan satu kamar lebih dominan dibandingkan dengan kamar lainnya. Kedua bikameralisme kuat atau bikameralisme simetris (strong bicameralism/ symmetric bicameralism) dimana masingmasing kamar di dalam lembaga perwakilan mempunyai kewenangan yang relatif setara. Ketiga bikameralisme sempurna (perfect bicameralism) yaitu dimana kewenangan kedua kamar di dalam lembaga perwakilan sama kuat (Sartori, 1997: 184).

Mengacu pada ketiga model bika- meralisme di atas dan mempertimbangkan dinamika politik di Indonesia, pilihan untuk menggunakan bikameralisme kuat atau bikameralisme simetris merupakan pilihan terbaik. Penggunaan model bikameralisme asimetris akan menegasikan fungsi salah satu kamar, sebagaimana yang terjadi pada saat ini dimana DPD tidak mempunyai kewenangan yang signifikan. Penerapan model bikameralisme sempurna memunculkan potensi konflik internal di antara DPR dan DPD karena kewenangan yang dimiliki sama kuat, sehingga menyulitkan proses pengambilan keputusan dalam badan legislatif. Selain itu juga akan berpotensi memperlambat kerja-kerja badan legislatif akibat sulitnya dan lamanya pengambilan keputusan yang disetujui bersama oleh kedua kamar.

Pilihan model bikameralisme kuat atau bikameralisme simetris menjadi jalan tengah oleh karena melalui penerapan model ini, DPR dapat tetap mempunyai kewenangan yang lebih luas atau lebih banyak dari DPD, misalnya dalam hal kewenangan legislasi terkait pengaturan materi tertentu atau dalam hal pengkonfirmasian jabatan-jabatan kenegaraan tertentu. Di sisi lain, terjadi penguatan kewenangan DPD agar mekanisme pengawasan dan pengimbangan secara internal dapat berjalan. Hal ini misalnya dapat dilakukan dengan memperkuat kewenangan DPD dalam proses pembahasan RUU, dimana DPD juga memiliki kewenangan untuk ikut serta dalam seluruh tingkatan pembahasan dan menyatakan persetujuan atau ketidaksetujuan terhadap RUU yang sedang dibahas tersebut. Dengan demikian, walaupun kewenangan legislasi DPD dibatasi pada keikutsertaan untuk membahas RUU secara limitatif sebagaimana diatur dalam UUD 1945 pasca amandemen, namun DPD selayaknya mempunyai kewenangan yang setara dengan DPR dalam proses pembahasan dan persetujuan terhadap RUU yang limitatif tersebut. Dengan kata lain, pembatasan terhadap kewenangan legislasi DPD dibatasi pada materi yang akan diatur dalam RUU, namun DPD mempunyai kewenangan penuh untuk ikut serta dalam pembahasan dan persetujuan terhadap RUU tersebut.

Namun demikian, upaya pengadopsian sistem perwakilan dua kamar (bikameral) sebagaimana tersebut di atas mengandung sejumlah problematika. Pertama, apabila sistem 
bikameral diterapkan, MPR akan kehilangan kedudukan sebagai lembaga yang permanen. Dalam sistem bikameral, kewenangan badan legislatif dibagi habis antara kamar pertama dengan kamar kedua. Dengan demikian, kewenangan badan legislatif akan dijalankan oleh DPR dan DPD, sedangkan MPR hanya merupakan joint session dan tidak memiliki struktur kelembagaan yang permanen. MPR hanya akan menjalankan fungsi dalam momenmomen tertentu, misalnya pada saat pelantikan presiden dan/atau wakil presiden, pidato kenegaraan presiden, atau proses pemakzulan terhadap presiden dan/atau wakil presiden. Upaya menginisiasi penerapan sistem bikameral oleh karenanya akan mendapatkan resistensi dari kekuatan-kekuatan politik atau kelompok-kelompok yang berkepentingan untuk mempertahankan MPR sebagai salah satu kamar yang bersifat permanen di dalam badan legislatif.

Kedua, apabila sistem bikameral diterapkan, DPD harus mempunyai kewenangan yang relatif signifikan dalam menjalankan fungsi sebagai badan legislatif, walaupun terdapat pembatasan dari segi jumlah atau keluasan kewenangan. Hal ini diperlukan agar DPD memenuhi kriteria redundancy untuk menjalankan mekanisme pengawasan dan pengimbangan secara internal (internal checks and balance) pada badan legislatif. Hal ini akan memicu resistensi dari kekuatankekuatan politik atau kelompok-kelompok yang tidak menginginkan DPD menjelma menjadi unsur dalam badan legislatif yang mempunyai kewenangan yang relatif setara dengan kewenangan DPR.

\section{Reposisi Majelis Permusyawaratan Rakyat Sebagai Lembaga Musyawarah Tertinggi Negara}

Oleh karena solusi untuk mengembalikan Peran MPR sebagaimana ketentuan UUD 1945 sebelum amandemen serta pengadopsian sistem bikameral akan menemui berbagai hambatan sebagaimana tersebut di atas, maka diperlukan upaya lain untuk melakukan reposisi terhadap kedudukan MPR dalam rangka menjamin efektivitas dan stabilitas penyelenggaraan pemerintahan, terutama dalam aspek relasi antar badan legislatif dan badan eksekutif.

Sebelum membahas tentang upaya reposisi kedudukan MPR, perlu untuk dicer- mati kembali filosofi dari para Founding Fathers ketika merumuskan keberadaan MPR. Soepomo dalam pidatonya di depan Sidang BPUPKI tanggal 31 Mei 1945 mengemukakan bahwa bangunan negara Indonesia harus mengacu pada struktur sosial masyarakat Indonesia asli, dimana salah satu cirinya adalah tradisi bermusyawarah. Selanjutnya Soepomo menyatakan ciri lain dari masyarakat Indonesia asli yaitu hubungan yang serasi antara pimpinan dan rakyatnya. Pemimpin harus bersatu jiwa dengan rakyat dan senantiasa wajib memegang teguh persatuan dan keseimbangan dalam masyarakat. Negara pada hakekatnya adalah seluruh masyarakat sebagai persatuan yang tersusun dan teratur dan tersusun. Oleh karena itu, negara tidak boleh mempersatukan dirinya dengan golongan yang terbesar dalam masyarakat, atau mempersatukan dirinya dengan golongan yang paling kuat dalam masyarakat. Sebaliknya, negara harus mengatasi segala golongan dan segala individu, serta harus mempersatukan dirinya dengan seluruh lapisan masyarakat (Silalahi, 2001: 270-271).

Pandangan Soepomo memperlihatkan bahwa struktur MPR harus mempertimbangkan ciri masyarakat Indonesia asli yang mengedepankan tradisi bermusyawarah. MPR dengan demikian tidak dibangun dengan model demokrasi modern yang mengedepankan kekuasaan oleh mayoritas (the rule of majority) yang dapat menegasikan aspirasi kelompokkelompok minoritas, melainkan melalui prinsip musyawarah dalam proses mencapai kesepakatan. Selain itu, relasi antara penguasa dengan rakyat yang selayaknya tercermin dalam kelembagaan MPR harus memperlihatkan relasi yang harmonis dan mengedepankan persatuan. Selanjutnya MPR harus dibangun dalam kerangka memperjuangkan kepentingan rakyat di atas kepentingan individu, kelompok atau golongan tertentu.

Pandangan tersebut diperkuat oleh pendapat Muhamad Yamin pada sidang BPUPKI yang menyatakan bahwa permusyawaratan berfungsi sebagai tempat untuk merundingkan keperluan negara atau keperluan umum (Sekretariat Negara, 1992: 149). Dengan demikian, jelas tergambarkan bahwa MPR dimaksudkan menjadi lembaga yang membahas hal-hal yang berkaitan dengan kepentingan negara atau kepentingan publik.

Selanjutnya Bung Karno dalam pidato 
di depan Sidang BPUPKI tanggal 1 Juni 1945 menyatakan bahwa dalam badan perwakilan, setiap masyarakat dapat mengemukakan segala sesuatu yang rasanya perlu dikemukakan. Oleh karena itu, masing-masing lapisan masyarakat harus berdaya upaya, supaya anggota-anggota badan perwakilan sebagian terbesar terdiri dari utusannya masing-masing. Dalam badan inilah terjadi perjuangan yang sehebathebatnya melalui musyawarah untuk mufakat (Sekretariat Negara, 1992: 272).

Pidato Bung Karno menyiratkan pesan bahwa MPR harus dapat mengakomodasi sebanyak-banyak perwakilan dari berbagai lapisan masyarakat, dan setiap keputusan yang akan diambil dalam badan tersebut harus dilakukan dengan memaksimalkan proses musyawarah untuk mufakat. Pemikiran Bung Karno tersebut dapat dipersandingkan dengan pemikiran tentang demokrasi deliberatif. Dalam proses deliberatif, keputusan-keputusan dibuat setelah melalui diskusi-diskusi yang mendalam dan penuh pertimbangan (Gastill and Levine, 2005: 6). Bahkan, kondisi ideal dari demokrasi deliberatif tidak hanya mengharuskan bahwa keputusan-keputusan berasal dari keinginan kolektif warga, namun juga mengedepankan pertimbangan-pertimbangan mendalam tentang kepentingan publik (Gastill and Levine, 2005: 20). Lebih lanjut, keputusan-keputusan yang dihasilkan menjadi absah karena merupakan hasil dari proses yang inklusif, dilakukan secara sukarela, penuh pertimbangan, dan dalam kondisi kesetaraan (Gastill and Levine, 2005: 27).

Berdasarkan pandangan para Founding Fathers tersebut di atas, terlihat bahwa MPR diproyeksikan untuk menjadi tempat untuk membicarakan permasalahan-permasalahan kenegaraan dan permasalahanpermasalahan kerakyatan melalui model demokrasi perwakilan. Proses pengambilan keputusan tersebut dilakukan melalui proses musyawarah untuk mencapai mufakat, dengan menghadirkan sebanyak-banyaknya ide atau gagasan yang mendalam dari sebanyakbanyaknya perwakilan dari berbagai unsur dalam masyarakat. Tersirat pesan bahwa proses demokratis dalam mengambil keputusan yang dilakukan dalam lembaga ini tidak dilakukan dengan prinsip suara terbanyak (the rule of majority), namun melalui proses deliberatif dengan mempertimbangkan secara mendalam berbagai aspek terkait permasalahan kenegaraan atau kerakyatan yang dibahas.

Selain itu, MPR harus menjadi forum yang merepresentasikan kepentingan seluruh rakyat, bukan menjadi forum kepentingan kelompok atau golongan tertentu. Hal tersebut dilakukan untuk menjamin persatuan bangsa sekaligus relasi yang harmonis di antara komponen-komponen bangsa. Dalam konteks ini, MPR dapat mengambil peran dalam membangun relasi yang harmonis antara badan legislatif dan badan eksekutif dalam rangka membangun pemerintahan yang efektif dan stabil.

Oleh karena MPR menjadi forum tertinggi dimana perwakilan-perwakilan dari seluruh unsur masyarakat memusyawarahkan persoalan-persoalan kenegaraan, kebangsaan, dan kerakyatan, maka MPR seharusnya mempunyai kewenangan untuk merumuskan arah tujuan dari negara Indonesia. Mengembalikan kewenangan MPR untuk merumuskan Garis-Garis Besar Haluan Negara (GBHN) menjadi penting karena MPR merupakan lembaga yang merepresentasikan kepentingankepentingan publik, dimana kepentingankepentingan publik tersebut dirumuskan melalui proses musyawarah untuk mencapai mufakat.

Dengan demikian, arah pembangunan negara dapat dirumuskan secara komprehensif karena proses formulasi yang dilakukan melibatkan seluruh pemangku kepentingan dan dilakukan melalui suatu proses deliberatif. Selain itu, rumusan arah pembangunan negara tersebut mempunyai nilai legitimasi yang tinggi karena tidak dirumuskan hanya oleh sekelompok orang namun mencakup perwakilan-perwakilan dari berbagai unsur dan lapisan dalam masyarakat.

Apabila proses formulasi arah pembangunan negara dilakukan melalui MPR, maka potensi konflik antara DPR dan Presiden akan dapat diminimalisasi. Perdebatan atau perbedaan antara kekuatan-kekuatan politik yang direpresentasikan dalam badan legislatif dan badan eksekutif yang memicu konflik akibat adanya perbedaan pandangan baik secara ideologis maupun praktis tentang arah pembangunan negara tidak lagi mengemuka, oleh karena hal tersebut telah diselesaikan dalam forum MPR. Dalam hal arah pembangunan negara, DPR dan Presiden berada dalam posisi memformulasikan dan mengimplementasikan 
berbagai kebijakan dan program sebagai turunan dari arah pembangunan negara yang telah dirumuskan dan ditetapkan oleh MPR.

Potensi konflik yang terjadi antara kekuatan-kekuatan politik yang mempunyai pandangan ideologis, programatis dan praktis yang berbeda dengan demikian didiskusikan dan diselesaikan di MPR sebagai forum tertinggi untuk memusyawarahkan persoalan-persoalan kenegaraan, kebangsaan dan kerakyatan. MPR oleh karenanya berperan sebagai lembaga untuk mengelola dan memoderasi konflik, termasuk di dalamnya konflik antara badan legislatif dan badan eksekutif.

\section{SIMPULAN}

MPR dan DPD sebagai bagian dari badan legislatif yang merepresentasikan kepentingan publik selayaknya mempunyai peran signifikan dalam membangun relasi yang ideal antara badan legislatif dan eksekutif. Relasi yang ideal tersebut ditunjukkan dengan minimnya konflik yang terjadi di antara badan legislatif dan eksekutif. Selain itu relasi yang dibangun tidak didasarkan atas politik transaksional demi kepentingan jangka pendek dari kelompok atau golongan tertentu.

Upaya reposisi kedudukan MPR dan DPD tidak dapat diarahkan untuk kembali menjadikan MPR sebagai lembaga tertinggi negara yang mempunyai kekuasaan yang tidak terbatas karena bertentangan dengan prinsip-prinsip demokrasi dan rentan untuk disalahgunakan oleh penguasa. Reposisi lembaga legislatif dengan demikian harus mengacu pada prinsipprinsip demokrasi.

Salah satualternatifyang dapat ditempuhadalah dengan menerapkan model bikameralisme kuat atau bikameralisme simetris, dimana mekanisme pengawasan dan pengimbangan internal (internal check and balances) berjalan di antara DPR dan DPD dalam menjalankan fungsi-fungsi badan legislatif. Sebagai konsekuensinya maka MPR tidak lagi menjadi lembaga permanen melainkan hanya sebagai joint session pada peristiwa politik atau momen kenegaraan tertentu.

Alternatif lain terhadap reposisi kedudukan lembaga legislatif dapat dilakukan dengan menjadikan MPR menjadi forum musyawarah tertinggi di antara berbagai komponen bangsa untuk membicarakan masalah-masalah kene- garaan, masalah-masalah kebangsaan, dan masalah-masalah kerakyatan melalui proses deliberatif diantara perwakilan dari berbagai unsur masyarakat. Hasil dari forum musyawarah tersebut dirumuskan ke dalam rencana pembangunan negara, bangsa dan masyarakat yang menjadi panduan bagi badan legislatif dan badan eksekutif dalam memformulasikan dan mengimplementasikan kebijakan-kebijakan dan program-program turunan dalam menyelenggarakan negara. Dalam kedudukan sebagai forum musyawarah tertinggi negara, MPR juga dapat berperan sebagai lembaga yang mengelola dan memoderasi konflik di antara kekuatan-kekuatan politik yang berada di badan legislatif maupun badan eksekutif.

Reposisi lembaga legislatif sebagaimana tersebut di atas diharapkan dapat menjadikan seluruh unsur dalam badan legislatif berperan secara optimal dalam menjalankan fungsinya, selain itu dapat mengurangi tarikan ke arah kepentingan politik transaksional jangka pendek yang berpotensi menciptakan konflik di antara kekuatan-kekuatan politik yang berada di badan legislatifdan badan eksekutif. Dengan demikian, relasi yang harmonis antara badan legislatif dan badan eksekutif dalam presidensialisme multipartai akan dapat diwujudkan. Relasi yang harmonis tersebut pada akhirnya akan bermuara pada terciptanya efektivitas dan stabilitas penyelenggaraan pemerintahan.

\section{DAFTAR PUSTAKA}

Ambardi, Kuskridho. (2009). Mengungkap Politik Kartel: Studi tentang Sistem Kepartaian di Indonesia Era Reformasi. Jakarta: Kepustakaan Populer Gramedia.

Asrinaldi, A. (2013). Koalisi Model Parlementer dan Dampaknya Pada Penguatan Kelembagaan Sistem Presidensial di Indonesia. Jurnal Penelitian Politik, 10 (2), 63-77.

Budiatri, Aisah Putri. (2015). Pelembagaan Sistem Kepartaian di Bawah Sistem Demokrasi Indonesia (1998-sekarang). Jurnal Penelitian Politik 12 (1), 33-54.

Barrington, Lowell. (2013). Comparative Politics, Structures and Choices. Wadsworth.

Gastil, John and Peter Levine (eds.). (2005). The Deliberative Democracy Handbook: 
Strategies for Effective Civic Engagement in the $21^{\text {st }}$ Century. San Francisco: JosseyBass.

Hanan, Djayadi. (2015). Memperkuat Presidensialisme Multipartai di Indonesia: Pemilu Serentak, Sistem Pemilu, dan Sistem Kepartaian. Seminar Memperkuat Presidensialisme Multipartai di Indonesia: Pemilu Serentak, Sistem Pemilu, dan Sistem Kepartaian, Universitas Indonesia, Depok.

Hanan, Djayadi. (2014). Menakar Presidensialisme Multipartai di Indonesia: Upaya Mencari Format Demokrasi yang Stabil dan Dinamis dalam Konteks Indonesia. Bandung: Mizan Media Utama.

Harris, Syamsuddin. (2014). Praktik Parlementer Demokrasi Presidensial Indonesia. Yogyakarta: Andi Offset.

Indrayana, Denny. (2008). Indonesian Constitutional Reform 1999-2002, An Evaluation of Constitutional-Making in Transition. Jakarta: Kompas.

Isra, Saldi. (2010). Pergeseran Fungsi Legislasi: Menguatnya Model Legislasi Parlementer dalam Sistem Presidensial Indonesia. Jakarta: RajaGrafindo.

Isra, Saldi (2004). Penataan Lembaga Perwakilan Rakyat: Sistem Trikameral di Tengah Supremasi Dewan Perwakilan Rakyat. Jurnal Konstitusi 1(1).

Lijphart, Arend. (1992). Parliamentary Versus Presidential Government. New York: Oxford University Press.

Loewenberg, Gerhard, et al., (eds.). (2005). Legislatures: ComparativePerspectives on Representative Assemblies. Ann Arbor: The University of Michigan Press.

Linz,Juan.1990. ThePerilsofPresidentialism, Journal of Democracy, Winter, 51-69.

Mainwaring, Scott. (1989). Institutional Dilemmas of Multiparty Presidential Democracy: The Case of Brazil. Paper for the XVInternational Congress of the Latin American Studies Association.

Mainwaring, Scott (1993). Presidentialism, Multipartiism, and Democracy: The
Difficult Combination. Comparative Political Studies, 26 (2), 198-228.

Manan, Firman.(2015). DPD RI dalam Sistem Pemerintahan Republik Indonesia. Jurnal CosmoGov, 1 (1), 48-61.

Manan, Bagir. (2003). DPR, DPD dan MPR dalam UUD 1945 Baru. Yogyakarta: FH UII Press.

Maxwell,JosephA.(1996). Qualitative Research Design: An Interactive Approach. California: SAGE Publications.

Mujani, Saiful et al. (2011). Kuasa Rakyat: Analisis Tentang Perilaku Memilih dalam Pemilihan Legislatif dan Presiden Indonesia Pasca-Orde Baru. Bandung: Mizan.

Patterson, Samuel C. and Anthony Mughan. (1999). Senates, Bicameralism in the Contemporary World. Columbus: Ohio State University.

Pereira, Carlos and Marcus Andre Melo. (2012). The Surprising Success of Multiparty Presidentialism. Journal of Democracy, 23 (3), 156-170.

Raile, Eric D., Carlos Pereida, and Timothy J. Power. (2010). The Executive Toolbox: Building Legislative Support in a Multiparty Presidential Regime. Political Research Quarterly, $X X(X)$, 1-12.

Sekretariat Negara RI. (1992) Risalah Sidang BPUPKI, PPKI. Jakarta: Sekretariat Negara.

Slater, Dan. (2004). Indonesia's Accountability Trap: Party Cartels and Presidential Power after Democratic Transition, Indonesia, 78, 61-92.

Sartori, Giovanni. (1997). Comparative Constitutional Engineering: An Inquiry into Structures, Incentives and Outcomes. New York: New York University Press.

Silalahi, S. (2001). Dasar-Dasar Indonesia Merdeka Versi Para Pendiri Bangsa. Jakarta: Gramedia Pustaka Utama.

Subekti, Valina Singka. (2008). Menyusun Konstitusi Transisi, Pergulatan Kepentingan dan Pemikiran dalam 
Proses Perubahan UUD 1945. Jakarta: RajaGrafindo Persada.

Wahid, M. Yunus. (2011). Proporsionalitas Kewenangan Lembaga Perwakilan Rakyat dalam UUD 1945. Jurnal Konstitusi. 3 (1), 1-23.
Yudha, Hanta. (2010). Presidensialisme Setengah Hati: Dari Dilema Ke Kompromi. Jakarta: Gramedia Pustaka Utama. 